\title{
The Prevalence of Complications After Spinal Anesthesia in Post-Surgical Patients
}

\author{
Alexander Siagian* \\ Department of Anesthesiology \\ Jenderal Achmad Yani University \\ Cimahi, Indonesia \\ *alex.siagian@fk.unjani.ac.id \\ Wendra \\ Department of Anatomy \\ Jenderal Achmad Yani University \\ Cimahi, Indonesia
}

\author{
Khansa Dea Shafira \\ Faculty of Medicine \\ Jenderal Achmad Yani University \\ Cimahi, Indonesia
}

\begin{abstract}
Spinal anaesthesia is a procedure that is currently being used a lot because of its benefit to relieve temporary pain sensation in patients without affecting patients' consciousness. However, this action can cause several complications. This study used a descriptive method to determine the complications of spinal anaesthesia based on sex, age, hyperbaric bupivacaine $0.5 \%$ drug dose being used, type of surgery, and needle size. The sampling method was total sampling, and the subjects were $\mathbf{5 7}$ patients who met the inclusion criteria. The data was taken from the medical records of patients who underwent surgery with spinal anaesthesia. The study showed the complications were headache, nausea, and vomiting, back pain, shivering, and urinary retention. The most common complication was headache which was felt mostly by females $(22.58 \%)$, age $26-45(37,61 \%)$, the drug dose given was $11-12.5 \mathrm{mg}(23.65 \%)$, and the needle size were 25 -gauge $(24,73 \%)$. The high prevalence of complications experienced by post-surgical patients can be considered an alarm and also highlights the importance of benefiting from skilled personnel and monitoring equipment in this unit.
\end{abstract}

Keywords—complications, spinal anesthesia

\section{INTRODUCTION}

Spinal anaesthesia is a regional anaesthetic procedure done by injecting anaesthetic drugs into cerebrospinal fluid (CSF) that surrounds the spinal cord [1]. It causes the area below the umbilicus to become numb without interfering with consciousness level. Indications for spinal anaesthesia include lower abdominal, perineal, obstetrics-gynaecology, urology, and lower extremities surgery [1]. There are major known contraindications to spinal anaesthesia. The absolute contraindications are lack of consent from the patient, elevated intracranial pressure (ICP) primarily due to intracranial mass, and infection at the site of the procedure (risk of meningitis) [1].

\author{
Pradiba Amadita \\ Faculty of Medicine \\ Jenderal Achmad Yani University \\ Cimahi, Indonesia
}

There are some benefits of spinal anaesthesia. It is a straightforward procedure compared to general anaesthesia, relatively cheaper, causing minimum systemic effects, and quicker recovery of digestive system function $[1,2]$. Lestari et al (2016) reported that $44.15 \%$ anaesthesiologists in West Java preferred spinal anaesthesia procedure [3]

Aside from its benefits, it also has its complications. There are some risk factors that play role in causing complications [3]. Patient's factors such as age and sex, anaesthesia factors such as needle size and anaesthetic drug being used, and surgical factors such as type of surgery and duration of the surgery [3]. Complications after spinal anaesthesia is categorized into intraoperative and postoperative complications $[1,4]$. Intraoperative complications are hypotension, bradycardia, cardiac arrest, hematoma, and spinal cord trauma. Postoperative complications are post-dural puncture headaches (PDPH), back pain, nausea and vomiting, shivering, transient hearing loss, and urinary retention $[1,4]$.

Considering the above facts, the present study aims to find out the prevalence of complications after spinal anaesthesia in a postsurgical unit.

\section{METHODS}

The present research was a descriptive study with the data taken from medical records. The study used total sampling to collect 57 data from patients that underwent a surgery using spinal anaesthesia in Hasan Sadikin Hospital in 2018. The inclusion criteria were patients that experienced complication(s) after spinal anaesthesia that was given bupivacaine $0.5 \%$ hyperbaric $7.5-12.5 \mathrm{mg}$. We excluded medical records with incomplete data such as no patients age, sex, surgery being done, needle type and size being used, no information about prior symptoms similar to complication, and 
if additional anaesthesia was given. The data was analysed using descriptive statistics (percentage, mean, and standard deviation) in Microsoft Excel and SPSS. This study was approved by the local Ethics Committee.

\section{RESULTS}

We included 57 medical records that fulfilled the inclusion criteria. Table 1 shows that headache was the most common $(36.56 \%)$ complication for the patients underwent a surgery with spinal anaesthesia. Nausea and vomiting and back pain had the highest prevalence after headache.

As per Table 2, $47.37 \%$ of the subject are males and $52.63 \%$ are females. The most common complication experienced by males were headache and back pain (both respectively $13.98 \%$ ). Headache was also the most common complication felt by females $(22.58 \%$ ) (Table 3$)$.

Headache was the most common complication experienced in all age categories, most of the subjects experienced it were in the age category of 26-45 years old (13.97\%) and followed by $46-65$ years old $(12.90 \%)$ (Table 4$)$. Table 5 shows that more complications prevalent in higher bupivacaine $0.5 \%$ dosage being used. Bigger needle size also caused more complications in the subjects (Table 6).

From Table 7, urology surgery caused the most (26.32\%) complications after spinal anaesthesia rather than other surgeries. The number followed by orthopaedic and obstetrics and gynaecology surgeries (both $24.56 \%$ ).

\section{DISCUSSION}

In this study, headache is the most common complication after spinal anaesthesia. Similar to previous studies, headache can be caused by the loss of cerebrospinal fluid (CSF) and traction in the meninges after the spinal procedure [5]. Nausea and vomiting are also common complications experienced by the subject. It can be caused by direct stimulation from an anaesthetic drug in the chemoreceptor trigger zone (CTZ) or visceral organ from a surgical area that sends afferent impulse through the vagus nerve [6]. Shivering and urinary retention experienced by some of the subjects. Shiver increases consumption of oxygen, which is necessary for the recovery process [7]. Urinary retention can be caused by undetected benign prostate hyperplasia (BPH), or the amount of anaesthetic drug being used in spinal anaesthesia [8]. The least experienced complication was transient hearing loss $(0 \%)$. There was no report of hearing loss, or it can be due to subjects paying less attention to it. Previous study reported that hearing loss after spinal anaesthesia is a rare complication and is a subclinical symptom so it should be cross-checked with audiometry [9].

From the study, back pain is the most common complication experienced by males. Females experienced more headache as the complication after spinal anaesthesia. Our findings strengthened Kwak's study, which reported that males have more amount and bigger size of muscle cells [10].
Headache, nausea, and vomiting are more common in females due to estrogen hormone [10]. Higher estrogen level in females cause increase in vascular distention as a response to CSF loss after spinal puncture [10]. Aging process is affecting the decrease of pain threshold. Muscle and blood vessel elasticity also decrease along with the aging process [11].

TABLE I. PREVAlENCE OF COMPLICATIONS AFTER SPINAL ANESTHESIA

\begin{tabular}{|l|l|l|}
\hline \multicolumn{1}{|c|}{ Variable } & \multicolumn{1}{c|}{ n } & \multicolumn{1}{c|}{$\%$} \\
\hline Back pain & 24 & 25.81 \\
\hline Headache & 34 & 36.56 \\
\hline Nausea and vomiting & 29 & 31.18 \\
\hline Shivering & 5 & 5.38 \\
\hline Urinary retention & 1 & 1.08 \\
\hline Transient hearing loss & 0 & 0 \\
\hline Total & 93 & 100.0 \\
\hline
\end{tabular}

TABLE II. GENDER PREVALENCE OF THE SUBJECTS

\begin{tabular}{|l|c|c|}
\hline Variable & n & \% \\
\hline Male & 27 & 47.37 \\
\hline Female & 30 & 52.63 \\
\hline Total & 57 & 100.0 \\
\hline
\end{tabular}

TABLE III. PREVALENCE OF COMPLICATIONS AFTER SPINAL ANESTHESIA BASED ON GENDER

\begin{tabular}{|l|l|l|l|l|l|l|}
\hline \multirow{2}{*}{ Variable } & \multicolumn{7}{|c|}{ Age (Years) } \\
\cline { 2 - 8 } & \multicolumn{2}{|c|}{$\mathbf{1 2 - 2 5}$} & \multicolumn{2}{c|}{$\mathbf{2 6 - 4 5}$} & \multicolumn{2}{c|}{$\mathbf{4 6 - 6 5}$} \\
\cline { 2 - 8 } & $\boldsymbol{n}$ & $\mathbf{\%}$ & $\boldsymbol{N}$ & $\mathbf{\%}$ & $\boldsymbol{n}$ & \multicolumn{1}{c|}{} \\
\hline Back pain & 5 & 5.37 & 9 & 9.67 & 10 & 10.75 \\
\hline Headache & 9 & 9.67 & 13 & 13.97 & 12 & 12.90 \\
\hline Nausea and vomiting & 9 & 9.67 & 11 & 11.82 & 9 & 9.67 \\
\hline Shivering & 3 & 3.22 & 2 & 2.15 & 0 & 0 \\
\hline Urinary retention & 0 & 0 & 0 & 0 & 1 & 1.07 \\
\hline Transient hearing loss & 0 & 0 & 0 & 0 & 0 & 0 \\
\hline Total & 24 & 27.93 & 37 & 37.61 & 32 & 34.39 \\
\hline
\end{tabular}

Bupivacaine $0.5 \%$ hyperbaric is a local anaesthetic that is largely used for spinal anaesthesia because of its long duration of action $[12,13]$. Our finding strengthens theory and previous study that higher drug dosage circulated in the bloodstream will increase complication risks [12,13]. Needle size and type play role in causing the size of a tear in the dura layer and how much CSF loss after the puncture $[1,2]$. The bigger needle size being used, the bigger rupture of meninges it will cause $[1,2]$. Quincke needle is said to cause more injury and more traction on the meninges and meningeal blood vessels rather than whitacre needle [1,2]. Anaesthesiologist at Hasan Sadikin Hospital did not use a whitacre needle due to economical reason and the hospital also got abundance supplies of Quincke needle from the government [3].

In this study, the surgery that caused complication the most after spinal anaesthesia is urology surgery, followed by lower extremity or orthopedic surgery, and obstetrics and gynaecology surgery. Different results were reported by Sholihah et al with orthopedic surgery caused complications the most after spinal anaesthesia [6]. It may be due to higher dosage used in urology surgery rather than other surgical departments [6]. 
TABLE IV. COMPLICATIONS AFTER SPINAL ANESTHESIA BASED ON BUPIVACAINE 0,5\% DOSAGE USED

\begin{tabular}{|l|l|l|l|l|}
\hline \multirow{2}{*}{ Variable } & \multicolumn{4}{|c|}{ Drug dosage (mg) } \\
\cline { 2 - 5 } & \multicolumn{2}{|c|}{$\mathbf{7 . 5} \mathbf{- 1 0}$} & \multicolumn{1}{c|}{$\mathbf{1 1}-\mathbf{1 2 . 5}$} \\
\cline { 2 - 5 } & $\boldsymbol{n}$ & \multicolumn{1}{c|}{$\%$} & \multicolumn{1}{c|}{$\boldsymbol{~}$} & \multicolumn{1}{c|}{} \\
\hline Back pain & 10 & 10.75 & 17 & 18.27 \\
\hline Headache & 12 & 12.90 & 22 & 23.65 \\
\hline Nausea and vomiting & 12 & 12.90 & 19 & 20.43 \\
\hline Shivering & 0 & 0 & 5 & 5.37 \\
\hline Urinary retention & 0 & 0 & 1 & 1.07 \\
\hline Transient hearing loss & 0 & 0 & 0 & 0 \\
\hline Total & 34 & 36.55 & 53 & 68.79 \\
\hline
\end{tabular}

TABLE V. COMPLICATIONS AFTER SPINAL ANESTHESIA BASED ON NEEDLE GAUGE SIZE

\begin{tabular}{|l|l|l|l|l|}
\hline \multirow{2}{*}{ Variable } & \multicolumn{4}{|c|}{ Quincke needle gauge size } \\
\cline { 2 - 5 } & \multicolumn{2}{|c|}{ 25 G } & \multicolumn{2}{c|}{ 26 G } \\
\cline { 2 - 5 } & $\boldsymbol{n}$ & \multicolumn{1}{c}{$\%$} & \multicolumn{1}{c|}{$\boldsymbol{n}$} & \% \\
\hline Back pain & 14 & 15.03 & 10 & 10.75 \\
\hline Headache & 23 & 24.73 & 11 & 11.82 \\
\hline Nausea and vomiting & 22 & 23.65 & 7 & 7.52 \\
\hline Shivering & 3 & 3.22 & 2 & 2.15 \\
\hline Urinary retention & 1 & 1.07 & 0 & 0 \\
\hline Transient hearing loss & 0 & 0 & 0 & 0 \\
\hline Total & 63 & 67.7 & 30 & 32.24 \\
\hline
\end{tabular}

TABLE VI. TYPE OF SURGERY THAT CAUSED COMPLICATIONS AFTER SPINAL ANESTHESIA

\begin{tabular}{|l|l|l|}
\hline \multicolumn{1}{|c|}{ Variable } & \multicolumn{1}{c|}{ n } & \multicolumn{1}{c|}{$\%$} \\
\hline Lower extremity & 14 & 24.56 \\
\hline Lower abdomen (periumbilical) & 6 & 10.53 \\
\hline Urology & 15 & 26.32 \\
\hline Obstetrics and gynecology & 14 & 24.56 \\
\hline Perineal & 8 & 14.04 \\
\hline Total & 57 & 100.0 \\
\hline
\end{tabular}

\section{STUDY LiMITATION}

Limited number of samples due to no interview was done on the sample or the anaesthesiologist because of restricted permits in the study methodology.

\section{CONCLUSION}

The high prevalence of complications experienced by postsurgical patients can be considered an alarm and also highlights the importance of benefiting from skilled personnel and monitoring equipment in this unit.

\section{REFERENCES}

[1] J.F. Butterworth, D.C. Mackey and J.D. Wasnick, Morgan \& Mikhail's clinical anesthesiology. New York: McGraw-Hill, 2013.

[2] M.S. Avidan, E. As, D.E. Longnecker, D.L. Brown and M.F. Newman The scope and future of anesthesia practice. In principles and practice of anesthesiology. New York: Anesthesiology McGraw-Hill, 2008.

[3] A.P. Lestari, S. Suwarman and M.A. Prihartono, "Survei Penggunaan, Jenis, Teknik, serta Obat Blok Saraf Perifer di Jawa Barat Tahun 2016,' Jurnal Anestesi Perioperatif, vol. 6, no. (3), pp. 175-182, 2018.

[4] H. Harsono, D. Tavianto and S. Suwarman, "Gambaran Penggunaan, Obat, Teknik, dan Permasalahan yang Dihadapi pada Blokade Kaudal di Kota Bandung Tahun 2016," Jurnal Anestesi Perioperatif, vol. 6, no. (3), pp. 200-206, 2018.

[5] D. Irawan, D. Tavianto and E. Surahman, "Kejadian Post Dural Puncture Headache dan Nilai Numeric Rating Scale Pascaseksio Sesarea dengan Anestesi Spinal," Jurnal Anestesi Perioperatif, vol. 1, no. (3), pp. 183$188,2013$.

[6] A. Sholihah, K.M. Sikumbang and A. Husairi, "Gambaran Angka Kejadian Post Operative Nausea And Vomiting (PONV) di Rsud Ulin Banjarmasin Mei-Juli 2014,” Berkala Kedokteran, vol. 11, no. (1), pp 119-129, 2015.

[7] S.S. Liu and S.B. McDonald, "Current issues in spinal anesthesia," The Journal of the American Society of Anesthesiologists, vol. 94, no. (5), pp. 888-906, 2001.

[8] A.A. aziz Niazi and M.A. aziz Taha, "Postoperative urinary retention after general and spinal anesthesia in orthopedic surgical patients,' Egyptian Journal of Anaesthesia, vol. 31, no. (1), pp. 65-69, 2015.

[9] F. Özkan, C. Düger, A. İspir, S. Gürsoy, K. Kaygusuz, K.O.L. İclal and C. Mimaroğlu, "Effects of spinal needle size on hearing functions in endoscopic urological operations," Cumhuriyet Medical Journal, vol. 32 , no. (4), pp. 334-339, 2010 .

[10] K.H. Kwak, "Postdural puncture headache," Korean journal of anesthesiology, vol. 70, no. (2), pp. 136, 2017.

[11] M. Joudi, M. Fathi, A. Dalili, S. Jahanbakhsh, A.M. Ardabili, M Akhondi and A. Izanloo, "The association of anesthetic method with developing back pain after lower extremity operations," Anesthesiology and pain medicine, vol. 4, no. (5), 2014.

[12] B.T. Finucane, Complications of regional and local anesthesia. 2nd ed Vol. 6, Current Opinion in Anaesthesiology. Alberta: Springer Science Business Media, LLC, 2007.

[13] L.L. Bready, S.H. Noorily and D. Dillman, Decision Making in Anesthesiology. Portland: Mosby Elsevier, 2007. 